\title{
ELŐSZÓ A II. FARKAS FERENC NEMZETKÖZI TUDOMÁNYOS KONFERENCIA (FFISC) KONFERENCIA BEST PAPER DÍJAZOTT TANULMÁNYAINAK BEMUTATÁSÁHOZ
}

2 020. május 29-én fogalmaztam meg a Farkas konferenciakötet előszavát a munkahelyi környezetemmé alakult dolgozószobámban. A dátum érdekességét az adja, hogy éppen aznap született 71 éve Farkas Ferenc professzor, akinek a nevét viseli a Pécsi Tudományegyetem Közgazdaságtudományi Kar Vezetés- és Szervezéstudományi Intézetének (PTE KTK VSZI) konferenciasorozata, melynek megrendezésére Pécsett, 2020. június 24-25-én került volna sor.

Manapság elképzelhetetlen időket élünk, és olyan helyzetekhez kellett alkalmazkodnunk 2020-ban, hogyha valaki ezt jósolja nekünk egy évvel ezelött, nem hittük volna el. Sajnos, a járvány olyan mértékben borította fel mindennapi megszokott életünk kicsi ladikját, hogy annak következményei még most sem beláthatók a számunkra. Vajon a Farkas Ferenc Nemzetközi Tudományos Konferencia (FFISC) megrendezhetö lesz-e két év múlva a jól megszokott személyes megjelenéssel, vagy az online megoldások veszik-e át a vezető szerepet, véget vetve a személyes találkozások és eszmecserék kollegiális légkörén alapuló tudományos diskurzusoknak?

Ezt ma még megjósolni sem lehet, de éppen ezért fontos ebben a globális léptékű, „,maszkos” bizonytalanságban valami megnyugtató kapaszkodót találni. Ezért döntött úgy az Intézetünk tudományos közössége, hogy nem mondunk le a hagyományainkról, s a képződő tudományos produktumokat - melyekből, hál' Istennek és a kollégáknak igen komoly mennyiség gyült össze - konferenciakötetbe rendeztük (elérhető a következő linken: https://digitalia.lib.pte.hu/hu/pub/balogh-laszlo-sipos-farkas-f-ii-nemzetkozi-tud-konf-2020-ptektk-pecs-2020-5004) és kiosztottuk a Best Paper díjakat is. Köszönöm mindenkinek a részvételt, s egyben szívből gratulálok a díjazottaknak, akiknek munkáiból a Vezetéstudomány folyóirat szerkesztőségének szakmai együttmüködésével jelennek meg az alábbi tanulmányok.

A konferencia Best Paper díjazott pályaművei a következők voltak

\begin{tabular}{|c|c|}
\hline Szerző/k/ & Az előadás /tanulmány/ címe \\
\hline Bencsik Andrea, Gódány Zsuzsanna, Máthé Márta & Interim menedzser szerepe a tudásmenedzsment-folyamatban \\
\hline $\begin{array}{c}\text { Fejes Nikoletta, Sandra Julian Schiemann, Eva Jonas, Dieter Frey, } \\
\text { Siegler Anna, Czibor Andrea }\end{array}$ & $\begin{array}{l}\text { The bright side of dark leaders: strengths of leaders with dark } \\
\text { personality traits }\end{array}$ \\
\hline Jakubik Mária & Reinventing management - is it an old wine in a new bottle? \\
\hline Musztyné Bátfai Boróka Viktória, Pótó Zsuzsanna & $\begin{array}{c}\text { Human Resource Management in the Public and Private Sectors } \\
\text { - an International Comparison with Special Focus on Central } \\
\text { Eastern Europe Based on Cranet Research 2004-2016 }\end{array}$ \\
\hline $\begin{array}{c}\text { Poór József, Juhász Tímea, Karácsony Péter, Kovács Ádám, } \\
\text { Szeiner Zsuzsanna, Csapó Ildikó, Horbulák Zsolt, Szitás Péter, } \\
\text { Hevesi Endre }\end{array}$ & $\begin{array}{l}\text { A szervezeti jellemzők hatása a munkaerőhiány kialakulását } \\
\text { előidéző okokra egy hazai empirikus kutatás tükrében }\end{array}$ \\
\hline $\begin{array}{c}\text { Obermayer Nóra, Csizmadia Tibor, Hargitai Dávid Máté, Kigyós } \\
\text { Tamás Attila }\end{array}$ & $\begin{array}{c}\text { Az Ipar } 4.0 \text { implemetációval kapcsolatos vezetői motivációk és } \\
\text { akadályozó tényezők elemzése hazai vállalatvezetők véleménye } \\
\text { alapján }\end{array}$ \\
\hline Sipos Norbert, Kuráth Gabriella, Gyarmatiné Bányai Edit & $\begin{array}{l}\text { A frissdiplomás kompetenciák és a bérek kapcsolata - a } \\
\text { kompetenciafejlesztés lehetőségei a felsőoktatásban }\end{array}$ \\
\hline Slavic Ágnes, Nemanja Berber, Marko Aleksic & $\begin{array}{l}\text { Relations between environmental responsibility and } \\
\text { environmental performances: an evidence from serbian } \\
\text { companies }\end{array}$ \\
\hline Szabó-Bálint Brigitta & A szervezeti karrierfejlesztés sikeres müködésének újragondolása \\
\hline Titkos Csaba, Nagy Norbert & A belső motivációs eszköztár terápiás hatása \\
\hline Venczel-Szakó Tímea, Balogh Gábor, Borgulya Istvánné & $\begin{array}{l}\text { Távmunka, home office: Hogyan érinti a távolról dolgozás a } \\
\text { szervezet intern kommunikációját? }\end{array}$ \\
\hline
\end{tabular}


Jelen Vezetéstudomány-számban az alábbi müveket közöljük, melyek kapcsán - gondolatébresztőül - szemezgettem a bírálók értékeléseiböl:

\title{
Bencsik Andrea - Gódány Zsuzsanna - Máthé Márta: INTERIM MENEDZSER SZEREPE A TUDÁSMENEDZSMENT-FOLYAMATBAN
}

\begin{abstract}
„Bencsik Andrea, Gódány Zsuzsanna és Máthé Márta tanulmánya a tudásmenedzsment egy kevésbé kutatott területét, az interim menedzsment tudásmenedzsmenttel való kapcsolódását vizsgálja. Szakirodalmi forrásokra és kvalitatív, mélyinterjús vizsgálat eredményeire támaszkodó írásuk mind az oktatás, mind a gyakorló szakemberek számára értéket képvisel. A tanulmány újszerü és aktuális, különösen a pandémia helyzet kihívásaira adott megoldáskeresésben.”

\section{Obermayer Nóra - Csizmadia Tibor - Hargitai Dávid Máté - Kigyós Tamás Attila: Az Ipar 4.0 implemetációval kapcsolatos vezetői motivációk és akadályozó tényezők elemzése hazai vállalatvezetők véleménye alapján}

\begin{abstract}
„A tanulmány nagyon aktuális témával foglalkozik, és azon belül is egy kiemelt kutatási területre koncentrál: az Ipar 4.0 jelenségére. A cikk a vállalatok téma iránti elöítéleteire, attitüdjeire fókuszál. A választott módszertan (interjúkészítés) megfelelö, hiszen a mögöttes szándékok és érzések feltárására alkalmasabb egy kvalitatív módszer, mint pl. egy kérdöíves megkérdezés. Az igen színvonalas munka újszerü és lényeges megállapításokat eredményezett, mint pl. hogy a vállalatok eleinte inkább tartózkodók, és aggódnak a technológiai változások kapcsán, ám ahol már megkezdték az Ipar 4.0 egyes elemeinek alkalmazását, ott azonban a pozitív tapasztalatok felülírják e félelmeket.”

\section{Venczel-Szakó Tímea - Balogh Gábor - Borgulya Istvánné: TÁVMUNKA, HOME OFFICE: HOGYAN ÉRINTI A TÁVOLRÓL DOLGOZÁS A SZERVEZET INTERN KOMMUNIKÁCIÓJÁT?}

„A pandémia miatt kényszerüen is előtérbe került egy nagyon jó (atipikus) foglalkoztatási forma, a távmunka, főleg a home office. De miközben a szakmai érdeklődés főleg a megvalósítás, az ellenőrizhetőség és költségelszámolás problémáira fókuszál, nem lenne szabad, hogy háttérbe szoruljon a belső kapcsolatrendszernek az új helyzethez igazítása. Balogh Gábor, Borgulya Istvánné és Venczel-Szakó Tímea tanulmánya azért fontos, mert erre a «hiányterületre» fókuszál. Mert tudjuk, hogy a munkavégzés legalább részben kívül történik majd, de ettől függetlenül (vagy épp ezért, különösen) fontossá válik, új gondolkodásmódot és megoldásokat, megújuló elméleti és gyakorlati közelítéseket igényel mind a formális, mind az informális kommunikáció a szervezet (menedzsment) és az érintettek, illetve a távmunkások egymás közötti kapcsolatában.”

Végül, kérem a tisztelt Olvasót, hogy reménykedjünk együtt abban, 2022-ben már úgy tudjunk adomázni erről a bizonyos 2020-as konferenciáról, hogy milyen furcsa világot is éltünk akkor és egyben felhívjuk egymás figyelmét, hogy a Farkas konferenciára menni kell, mert „.... víz szalad, a kő marad, a kő marad” (Wass Albert)!

Pécs, 2021. január 10. 